\author{
The Social Identity Change of Little Bee as the Main Character \\ in Chris Cleave's The Other Hand
}

\author{
Riska Hendika Rani
}

Universitas Sebelas Maret

Author Note

Author is student of English Department, Faculty of Cultural Sciences, Universitas Sebelas Maret, Jalan Ir. Sutami 36A, Surakarta, Indonesia 


\begin{abstract}
Chris Cleave's novel entitled The Other Hand pictures an African refugee's life in the United Kingdom and her struggle to survive in the country. As an illegal refugee from Africa who smuggles herself into a tea ship, Little Bee, the refugee, has to stay in the immigration detention center when she arrives in the United Kingdom. She deals with identity issues during her twoyear-stay in the immigration detention center. The questions such as 'why don't British people treat her in a good way' and 'why do British people get respect and she does not' make her want to be treated like a British, which she assumes, being treated nicely in the United Kingdom. Under the paradigm of social identity theory which contains the three stages of identity formation proposed by Henri Tajfel and John Turner, this study attempts to explain Little Bee's process of identity formation. Focusing on Little Bee's struggle in the United Kingdom as an illegal refugee from Africa, this study analyzes the three stages of identity formation that Little Bee has been through during her social identity transformation, as well as the factors influencing her and her struggle during the process.
\end{abstract}

Keywords: The Other Hand, Little Bee, Social Identity, Social Identity Change, Tajfel and Turner 


\section{The Social Identity Change of Little Bee as the Main Character in Chris Cleave's The Other Hand}

The novel entitled "The Other Hand", also known as "Little Bee" in the US and Canada, tells about a girl who calls herself Little Bee. She is a refugee from Nigeria who come to Britain by smuggling in a tea ship. She has lived in a detention center for two years before she is released.

In her two years living in the detention center, she has experienced the day-to-day realities which lead her to question her own identity such as whether it is important for her to live or how to survive in this great country. For some reasons, she feels being encouraged to adopt a new identity in order to be able to survive. The novel pictures the life of a refugee in Britain.

The condition of British immigration detention center surely gives an impact to the refugees. Most of the refugees, especially children with age of 0 month until 18 years, suffer mentally and physically. In the detention center, the refugees are isolated and they live under a strict policy. Thus, they do not get mental support from their family and friends, including from those who live in the same detention center. They also suffer from hunger since it is difficult to get nutritious food. Instead, they sometimes get limited amount of food. This condition affect their personality (Lorek et al., 2009: 575-585).

The author of the novel, Chris Cleave wants to picture the influence caused by a certain event in the past which can change someone's life entirely through Little Bee's story. He got the idea after spending his time by being a volunteer in a detention center. He experienced and witnessed how the people in the detention center lived, so he understood their struggle. On "The Other Hand", Little Bee represents a girl who gets mental effect from being locked up without being able to see the outside world. She wants to be freed, she wants to change her social identity 
as a part of the illegal refugee into something else in order to be respected as a person. However, her two-year-detention-center-life she has experienced does not seem to be the only reason for her social identity change.

Researches on identity in literary works are conducted to look at several objects. In Social Identity Theory in Toni Morrison's Sula, the events in the story affect the characters' identity formation. Using Henri Tajfel's identity theory, this research found tough condition where they suffer discrimination and cruelty due to Sula's and other characters' skin color takes a huge part in the process of their identity formation (Ramin and Yadohllah, 2014) Meanwhile, The Identity Games in Paul Auster's the Book of Illusions which uses Antony Giddens' modernity and self-identity theory shows how trauma from the past take a big role in forming the character's identity. Paul Auster uses the character's trauma to form the characters' identity, make them into someone, and make them have desire to be someone they want to (Pascu, 2014). On the other hand, the research entitled Pride and Prejudice and Social Identity Theory uses social identity theory by Tajfel and Turner to analyze Jane Austin's characters behavior. The characters who belongs to a certain group tend to have pride because of their status. Meanwhile, when they see other the characters who belong to the other group, they tend to judge or have a prejudice toward them (Lorenz, 2018). This research also applies Tajfel and Turner's social identity theory to analyze a novel entitled on The Other Hand by Chris Cleave. Focusing on Little Bee's process of social identity change during the story, this research also analyzes the factors influencing her social identity change. 


\section{Methods}

Identity makes one particular person or group different from others. One person tends to act and to behave like those who belong to the same group with them. However, it is possible that one person belongs to various social groups, and the way they act depends on who they are associated with (Tajfel and Turner, 1986: 7-24).

Identity is an important aspect pictured in literature to define a character through language of literature. Language of literature shows the author's 'emotion', 'thought' and 'feelings' in order to draw the readers' emotion into the story. Poems, epics, lyrics, novels, and plays are the example of works that use the language of literature (Wallek \& Warren, 1956).

Novel, as one of the imaginative literature, often pictures a social phenomenon. It has seven aspects: story, characters, plot, fantasy, prophecy, pattern, and rhythm. A story is a narrative of events arranged in the time sequence. Characters are not real people, but they are like real people who live in the novel. Of course, their lives are different from real lives. Sometimes, they seem to be more real than the people around us. The reason is because the author is able to show their hidden life. Plot is the relationship between cause and effect. Fantasy implies the supernatural while prophecy is an accent in the novelist's voice. Pattern is an aesthetic aspect of the novel. Meanwhile, rhythm is like musical motive which reappears with slight variation and helps to unify the novel (Forster, 1956).

Social identity theory is applied as the approach to understand the novel. Tajfel and Turner (1986) develop social identity theory, including the concept of a person's self which comes from the group where this person belongs. It is possible for a person to act differently in a different social context. For example, a married woman who is also a teacher will act as a teacher in school. However, once she comes to the the neighborhood, she will become a wife. 
When a person is aware of himself being in a part of a certain group, it is an 'ingroup' for them. However, when someone does not consider himself as a part of a certain group, that is an 'outgroup' for them. In this situation, there will be "us" and "them". According to this theory, there are three processes in creating 'ingroup'/ 'outgroup mentality'; social categorization, social identification, and social comparison.

Social categorization is the process when we categorize people in order to identify and understand them, for example; teacher, student, white, black, etc. Social identification is the process of adopting the behavior, or the identity we belong to. For example, the first year of a university student's life is the time when he needs to adapt himself. Sometimes, they will learn from their seniors or their friends. This is what we call as social identification. Social comparison is the process where a person tends to compare himself to the other persons, especially those who belong to the other group, or to compare their group with the other groups (Tajfel and Turner,1986: 7-24).

\section{Result}

Little Bee's social identity change in the novel the Other Hand by Chris Cleave is caused by four factors. They are her envy towards British people's easy life, her needs to tell her sad story, her will to survive, and her desire to overcome her past. The first factor is the envy Little Bee feels when she finds out her life is way more difficult than British people. She even thinks, a British pound coins will have an easier life than her. She also see British as people who have a bright future, unlike her, an African, not to mention, a refugee.

"Most days I wish I was a British pound coin instead of an African girl. Everyone would be pleased to see me coming..." (p. 1). 
Little Bee is a girl, an African, and most people do not look at her or consider her just nothing. Little Bee expects herself to be treated like British pound coin which people appraise it highly. The phrase 'see me coming' above can have meanings other than 'to look at her' or 'to see her come'. The word 'bee' in which she refers herself to the treatment she gets when she is in the United Kingdom. Just like a bee, not everyone likes her as an African girl. Her awareness that not every person treats her well, equalizing herself with a bee shows her social comparison stage (Tajfel and Turner, 1986).

"So, I am a refugee, and I get very lonely. Is it my fault if I do not look like an English girl and I do not talk like Nigerian? Well, who says an English girl must have skin as pale as the clouds that float across her summers? Who says a Nigerian girl must speak in fallen English, as if English has collided with Ibo, high in the upper atmosphere, and rained down into her mouth in shower that half drowns her and leaves her choking up sweet tales about bright African colors and the taste of fried plantain? Not like a story teller, but like a victim rescued from flood, coughing up the colonial water from her lungs?” (p.12)

The situations experienced by Little Bee and her social awareness through comparing her self-identity and the people around her show how three stages of social identity formation as described by Tajfel and Turner happen to Little Bee. The first stage, as explained previously is her awareness that she is a refugee from Nigeria. The second stage can be seen from the way she begins to recognize how most Nigerian speak English with certain accent while comparing them the way British people speak in their own native language. And the third stage is her social 
awareness that she is socially inferior compared to British because she does not speak like Native British people. It shows how the three stages are related to each other (Tajfel and Turner, 1986).

By the process, she begins to question the reason why she cannot have a peaceful life in Britain. She keeps aside the fact that she does not have any papers as a requirement to be accepted legally in the United Kingdom. With her most effort to speak English like Native, she thinks she deserved to be treated like an English girl although she does not look like ones.

Little Bee does not look like English girls, but she can speak English as good as them. Later on, she adds that being Nigerian does not mean lacking the ability to speak proper English. In her opinion, not all Nigerian speak broken English, or English which is being mixed with other languages, in this case, with Ibo, or Igbo, one of the largest languages being used in West Africa. She disagrees with the thought of Nigerian speaking English like a flood victim, which means, having a great amount of difficulties when they try to say something in English. The prejudice once again happens in this social comparison stage. Although it is not clear where Little Bee has heard it, she believes the British has prejudice to Nigerians who cannot speak proper English. From the situation above, we can see how Little Bee uses different objects to illustrate the relationship and comparison between African and British. During the social comparison stage, there is a high possibility for this kind of situation to happen where a person or a group tend to have prejudice toward the 'outgroup' members (Tajfel, Flament, Billig, \& Bundy, 1971: 149-177). Not only does Little Bee categorize herself as an African, but she also labels herself as a refugee. It is a proof that it is possible for her to have multiple social identities (Tajfel and Turner, 1986). Little Bee tries to form her British social identity, although she does no look like British in her look. 
The second factor which makes her wants to change her social identity is to her desire to share her story to others, especially, her sad story. Little Bee expresses her will to tell her story using the proper English to make people understand her background as well as the event which has happened in Nigeria which has made her and her people in her village suffer.

"I am sorry to learn your language properly. I am here to tell you a story" (p. 12).

Little Bee says that she learns English intentionally. Your language stands for English since the language she learns in the detention center is English, and you stands for English speakers. She aims for something after she is able to speak English properly, which is telling us a story.

In the social categorization stage, she comes into an understanding of labelling herself into such as: I am an African girl, I am a refugee. While, her social comparison stage is in her awareness which leads her to be able to tell the situation which has happened during her twoyear stay in Black Hill Detention Centre. Meanwhile, the social identification stage is the story she calls as a sad story, or sometimes, the horror.

“... Now the horror can speak the Queen's English. This is how we can speak now of sanctuary and refuge. This is how I can tell you - soon-soon as we say in my country - a little about the thing I was running from" (p.67).

Little Bee mentions her purpose to learn the Queen's English. She wants to tell us about her story, especially her horror. She feels sad whenever she speaks about her horror, that is why 
she mentions earlier that the story she wants to tell is a sad story. Little Bee wants to tell her story in a proper language, so the people who hear her story could easily understand. She wants people to know what she has been through. The phrase the horror can speak the Queen's English does not mean her trauma speaks on its own. By saying those words, Little Bee wants us to know that she is able to tell us her sad story using proper English.

The third reason is to survive. Actually, even before trying to change her social identity, Little Bee has changed her individual identity; her name, with the hope to be able to save herself from the hunters. After she had arrived in the United Kingdom, she tries to change her social identity, too. Therefore, she expects to be safe.

As a refugee, she has fears, such as, being treated badly, or even being killed. According to Little Bee, the reason why she is safe in the detention center is because she learns the Queen's English. The English she talks about refers to the English being used by British, especially, the Queen herself.

"Why did I go to all the trouble? It is because of what some of the older girls explained to me: to survive, you must look good or talk even better..." (p. 4).

The other reason Little Bee wants to speak English properly is because the older girls in the detention center told her about two ways to survive in the detention center. First, Little Bee has to look good, to be pretty and attractive. The second way to survive is to speak even better, which can be interpreted as, to be smart. Her insecurity while comparing herself to the outgroup encourages her will to change her social status in order to survive (Tajfel and Turner, 1979). 
The fourth reason is to overcome her trauma. Little Bee has a fear about her past. Her older sister is raped, killed, and eaten by the hunters. She is afraid they will find her even when she is in the United Kingdom.

“...Freedom for me is a day when I am not afraid of the men coming to kill me. Freedom for Sarah is a long future where she can live the life of her choice. I do not think she is weak or foolish for living a life she was born in. A dog must be a dog and a wolf must be a wolf - that is the proverb in my country" (p. 254).

Little Bee runs away from his country because there is an oil war in her homeland, Nigeria. The war becomes a traumatic event which still haunts her up to the present. Therefore, she wants to be free from her past. One of her effort is learning to speak proper English, so people could not know that she is actually a refugee, an illegal person in the United Kingdom. Although she wants to take off her tittle as a refugee, and wants to look more British, she keeps in her mind that she is always an African girl, a Nigerian, just like the proverb in her country says.

Little Bee has indeed learned those things about freedom and the proverb from her social identification stage while she was still in Nigeria. In this stage, a person will try to imitate his group's behavior, as well as learning the moral value from them (Tajfel and Turner, 1986).

"Yevette moved her mouth close to my ear. 'It ain't save out ere.' 'But they have released us, haven't they? We are free to go. What is the problem?' 
Yevette shook her head and whispered again. 'Ain't dat simple, darlin. Dere's freedom as in, yu girls is free to go, and den dere's freedom is in, yu girls is free to go till we catches yu. Sorry, but it's dat second kind of freedom we got right now, Lil Bee. Truth. Dey call it bein illegal immigrant.' “ (p. 73)

For once, Little Bee thinks she is free to do anything in the United Kingdom. However, Yevette, one of the girls from the detention center, reminds her that they have no papers to proof they are legal to live in the country. Little Bee, once again, has to step on the social identification stage where she learn how to live as a refugee in the United Kingdom (Tajfel and Turner, 1986). It is different from the value she learned in her hometown since refugee and African are two different groups. The different groups have differences in their value and behavior (Stets and Burke, 2000: 224-237).

"If the men come suddenly, I will be ready to kill myself. Do you feel sorry for me, for thinking always in this way? If the men come and they find you not ready, then it will be me who is feeling sorry for you" (p. 68).

Actually, Little Bee is still afraid of the men who killed, raped and ate her sister. She always thinks about killing herself when they finds her. However, it does not stop her for trying to change herself to be a person who deserves to get a better life in the United Kingdom. The reason she wants to be someone in a better social status correlated to what Tajfel and Turner (1979) has pointed out is on her attempt to get higher social status in order to be more secure about one's self. Little Bee wants to change her social identity, so they could not recognize her as the Little Bee whom they have failed to kill when she was still in Nigeria, Africa. 
The envy Little Bee feels appears during her social comparison stage. However, in the social identification while she was still in Nigeria, Little Bee also experienced the oil war which caused her desire to change her social identity. Also, when she categorizes herself as an illegal refugee, Little Bee wants to change her social identity even more. Therefore, all three stages of social identity theory as proposed by Tajfel and Turner have a potency to be the factor of someone's social identity change.

Most of the things Little Bee does to change her social identity is learning the language and the way British community life in the United Kingdom. She reads books, novel, and newspapers provided in the detention center, then looks for the difficult words in the dictionary.

"I have read that the people around her - even Kings and Prime Ministers - they find their bodies responding to her orders even before their brains can even think why not. Let me tell you, it is not the crown and the sceptre that have this effect. ... It is her grammar and her voice. That is why it is desirable to speak the way she does." (page 3)

The quotation above does not explain clearly what Little Bee has read. Aside from this fact, we can draw a conclusion that Bee has the stereotype about how a person should talk in English in order to get respect from others. The grammar used by the Queen when she speaks, her voice, as well as her tone and intonation, are the things she tries to imitate from the British. Therefore, she learns the proper English, which she often calls as the Queen's English, in order to get the respect from others while she lives in the United Kingdom. Now, when she is living in the country among the British community, Little Bee tries to change herself to be the part of their 
group. She is in her social identification stage where she tries to imitate British way to speak, the accent, also the grammar.

“...I was realising, right there, that it was one thing to learn the Queen's English from books and newspapers in my detention cell, and quite another thing to actually speak the language with the English. I was angry with myself. I was thinking, You cannot afford to go around making mistakes like that, girl. If you talk like savage who learned her English on the boat, the men are going to find you out and send you straight back home. That's what I was thinking" (p. 5).

Later Little Bee explains how she has learned and practiced to speak English properly through books and newspaper in the detention center. She keeps telling herself not to make mistakes while talking. This shows how serious she is to be able to speak the Queen's English.

"The morning they let us out of the detention centre, they gave us all our possessions. I held mine in a see-through plastic bag. A Collins Gem Pocket English Dictionary, one pair of grey socks, one pair of grey briefs, ..." (p. 12-13).

One of the sources for Little Bee to learn English is a Collins Gem Pocket English Dictionary. She carries it with her when she gets out from the immigration detention center. It means, she is serious about learning English properly to the point of carrying around a dictionary although she is already good enough in speaking English. 
"In the canteen there was a television that was always on. I began to learn more about life in your country. I watched programmes called Love Island and Hell's Kitchen and Who Want's To Be A Millionaire? ..." (p. 71).

Not only learning by reading, Little Bee attempts to improve her English by watching TV shows. She learns the gestures, intonations, as well as the tones in attempt to speak proper English. She also learns the British culture from the shows.

Little Bee is categorized as the disadvantage group as a refugee in the United Kingdom. Therefore, she wants to get more recognition from British and change her social identity (Tajfel and Turner, 1979). She wants to get a better life in the United Kingdom by learning their language, because learning the language is one of the limited things she could do when she was still in the Black Hill Immigration Removal Centre. Therefore, people will not see Little Bee as a refugee, in this case illegal citizen, anymore. By having this in mind, Little Bee hopes she will have a peace life in the United Kingdom.

Using Tajfel and Turner's theory on social identity change, this research also identifies the three stages of the process of Little Bee social identity transformation. She categorizes herself as a refugee who has a difficult life in the immigration detention center. She sees those who live a happy life in the United Kingdom as British, unlike her who has to struggle in order to survive. She also has prejudice toward the other group (Lorenz, 2018), even though she is not proud to be an illegal refugee. Little Bee's drive to change her social identity status is entangled with her low esteem of being discriminated by people around. Such situation is also identified by Ramin and Yadohllah in analyzing Tony Morison's Sula using similar theory. Similar with Pascu's argument that trauma also drives the character to change her identity, Little Bee also 
experiences traumas which leave mark on her heart (Pascu, 2014). However, in the story Little Bee attempts to recover from her trauma through spelling out her past story she has been through to ask their attention and their understanding that she deserves to be treated well. To reach the goal, she learns how to speak English properly with an expectation of being recognized.

Therefore, she will be able to survive living in the United Kingdom with the change on her social identity status.

\section{Conclusion}

As an illegal refugee from Africa, Little Bee experiences several events which influence her will to change her social identity. Not having a good environment to stay in the immigration detention center makes her think that the British people do not treat her well because she is a refugee from Africa. She categorizes herself as a refugee from Africa. Meanwhile, the people around her categorize her and treat her also as the refugee. Little Bee often identifies the things which make her looks like an African. She also looks for the things which make someone a British. Sometimes, she identifies them separately; at other times, she identifies while compares British and African. The process she has been through to change her social identity is correlated with Tajfel and Turner's theory of social identity formation. Little Bee also experiences the three stages as mentioned by Tajfel and Tunner to form her new social identity. Being an African illegal refugee, she envies the British's life, which she identifies, is easier than her life while she compares refugees to the British. She intends to tell them how hard her life is to show them that she deserves to be treated well. Little Bee has a strong desire to survive living in the new environment even though she is in the disadvantage group. She wants to overcome her trauma caused by the oil war in Nigeria and live her new life in the United Kingdom. She has been through the social categorization stage, social identification stage, as well as social comparison 
stage in the process of changing herself in order to look like a British, not in the physical way, but in the way she talks, the way she acts, and the way she thinks, with an expectation to be treated in a good way, just like the way a British treats each other. 


\section{References}

Cleave, Chris. (2008). The Other Hand. London: Sceptre.

Forster, E.M. Aspects of the Novel. Mariner Books. (1956)

Lorek, A., Ehntholt, K., Nesbitt, A., Wey, E., Githinji, C., Rossor, E., Wickramasinghe, R. (2009). the mental and physical health difficulties of children held within a British immigration detention center: A pilot study. Child Abuse \& Neglect. 33(9). 573-585.

Lorenz, Matt. (2018). Pride and Prejudice and Social Identity Theory. In B. Lau (Ed). Jane Austen and Science of the Mind. (pp: 115-135). London. Routledge.

Pascu. A.O. (2014). The Identity Games In Paul Auster's The Book of Illusions. Research and Science Today. 1(3). 221-228.

Ramin, Z., \& Yadollahi, N. (2014) Social Identity in Toni Morrison's Sula. International Jurnal of Women's Research. 3(1), 93-104.

Stets, Jan E. \& Peter. J, Burke. (2000). Identity Theory and Social Identity Theory. Social Psychology Quarterly. 63, 224-237.

Tajfel, H., \& Turner, J. (1979). An integrative theory of intergroup conflict. In W. G. Austin \& S. Worchel (Eds.), The social psychology of intergroup relations (pp. 33-48). Monterey, CA: Brooks/Cole.

Tajfel, H., Flament, C., Billig, M. G., \& Bundy, R. F. (1971). Social categorization and intergroup behaviour. European Journal of Social Psychology, 1, 149-177.

Turner, J.C., \& Tajfel, H. (1986). The Social Identity Theory of Intergroup Behavior. Psychology of Intergroup Relations, 7-24. 
Wellek, René, \& Warren, Austin . (1956). Theory of Literature, 3rd ed. New York: Harcourt, Brace \& World. 